\title{
Archaeological perspectives on prehistoric conservation in western North America
}

\author{
TERRY L. JONES* \\ Department of Social Sciences, California Polytechnic State University, San Luis Obispo, \\ CA 93405, USA
}

\begin{abstract}
The archaeological record represents a potentially critical source of information on past relationships between human hunters and populations of game animals. Archaeological research in the last 40-50 years has produced two alternative views on these relationships: one that Native people were knowledgeable, benevolent conservators of game and an alternative that suggests that they depleted and suppressed game populations through overhunting. A brief review of the history of this research shows that neither position is well-supported by empirical facts and that researchers have demonstrated a certain overzealousness in attempting to support one or the other of these interpretations. The facts are that after more than 13,000 years of non-conservative hunting, game populations were still extremely high across North America. This suggests that populations of Native hunters were relatively low, and that the former productivity of North American ecosystems may be under-estimated by modern conservators.
\end{abstract}

There are findings from archaeology, anthropology and history that speak to issues of game conservation in western North America and beyond. The pre-Columbian game populations and ecology, and the perception of them by modern people, play a pivotal role in contemporary attempts at conservation. Pre-European game populations are often considered a baseline for comparison with present-day situations. Since the 1960s, archaeologists and anthropologists have become increasingly aware of the potential for their research to contribute to such perceptions. Meantime, American archaeology has also become more theoretically-focused and politically conscious, so that some practitioners have approached the historic and archaeological record of past human-game relationships with specific objectives in mind. Thus, findings and interpretations about the presence or absence of game conservation ethics and procedures in pre-contact Native America derived from archaeology include a complex amalgam of theory, opinion and fact. The factual picture is not yet complete.

In this brief review, I shall examine some of the research by anthropologists and archaeologists on issues of game populations, hunting and conservation in prehistoric western North America, with a particular focus on California. This area has been the focus of much research on the topic and it can in some ways be considered representative of the rest of the continent. As a general observation, it should be recognized that most research 
on this topic is dominated by two opposing views: the first, consistent with the longstanding myth of the 'noble savage' is that Native Americans had few if any negative impacts on game populations and that they should be viewed as the ultimate stewards of North American biota. The second and opposing view is that over the course of 13,000 years of hunting, Native Americans had noticeable impacts on the size and distribution of faunal populations, in many cases suppressing populations through overexploitation that was the result of constant, incremental growth in human populations. As I will discuss below, these views have swung like a pendulum with heavy emphasis on theoretical/political predispositions but with less on the empirical facts. Krech [1] has referred to these polarized views as the Noble Savage versus the Ignoble Savage, terms that reflect the alternate perspectives from which archaeologists and historians have tended to view the empirical record. In my view, the empirical record suggests that the truth lies somewhere in between.

\section{The 'Noble Savage' and contact-era biota in North America}

One important theme is the relative abundance of wildlife on the North American continent at the time of the arrival of Europeans. Of course, there is no way to measure accurately the numbers of fish in the rivers or game in the forests in 1492 . We are forced to rely on historic accounts written by the earliest explorers and settlers. These are a far from perfect source because in some cases authors may have had ulterior motives when penning their descriptions, for example, trying to encourage Europeans to immigrate by describing exceptionally plentiful resources. Nonetheless, virtually every such account from both the west and east coasts of the continent describes remarkably rich wildlife with prolific populations of mammals, fish, and shellfish. In 1630 in Massachusetts, for example, Francis Higginson [2] wrote that 'the abundance of sea fish are almost beyond believing', and that a 'store of blessings' was ripe for the taking by English colonists. In Virginia, accounts described 'incredible abundance' of wild life 'most beautiful and pleasant to behold, replenished with deer, conies, hares and divers beasts and about them the goodliest and best fish in the world in great abundance' [3]. On the west coast in California, the earliest accounts by explorers and missionaries are equally effusive in terms of the richness of the resource base. In 1579, for example, Sir Francis Drake described the area north of San Francisco Bay as '... a goodly country and fruitful soil, stored with many blessings fit for the use of man: infinite was the company of large fat deer, which there we saw by the thousands as we suppose in a herd' [4]. In 1785, 16 years after the establishment of the first permanent Spanish settlements in California, Jean Francois La Perouse ([5] I, p. 441) wrote that 'No country is more abundant in fish and game of every sort ... partridges alone are found in covies of three or four hundred'. Even later in the 1830 s, Wilkes [6] noted in central California that 'the variety of game in this country almost exceeds belief'. Many similar accounts exist for California and other western states, and there is little reason to question the apparent fact that animal populations were extremely robust across the North American continent at the time of the arrival of Europeans. All available historical evidence suggests that populations of game animals were high when the Spanish arrived in California and that they continued so through most of the nineteenth century. For large terrestrial mammals, populations seem to have been higher at the contact era and during prehistory than they have been in the twentieth century.

Because these animals were subsistence resources for Native Americans and were regularly hunted with a myriad of highly effective methods, the question is how could it 
be possible that large numbers of animals co-existed with substantial populations of human hunters? This question was not faced by anthropologists or archaeologists until the 1960s when the inter-relations and interactions between human populations and their environments became a major focus of archeological research. Almost immediately, two alternative views emerged: one that envisioned Native Americans, particularly Native Californians as knowledgeable game managers and conservators, and the other that portrayed them as highly-skilled, self-interested hunters who readily overhunted certain species (e.g. Pleistocene megafauna) into extinction.

\section{Legacy of the 1960s I: Native Americans as environmental managers}

Salvage ethnographies and ethnohistories that were compiled on the Native peoples of western North America in the late nineteenth and early twentieth century provide little if any substantive evidence for game conservation actions. Most typically, such sources identify the animals that were exploited and the methods used to acquire them. Nonetheless, a popular hypothesis that emerged in the late 1960s and later evolved into quasi-fact was the notion that the richness of the North American resource base was the direct result of management activities by Native peoples. In California and elsewhere, the main focus of this hypothesis was controlled burning [7-9], the positive effects of which had been ignored by mainstream American science during the first half of the 20th century. That California landscapes benefit from the application of fire has clearly been established [10] and that Native peoples conducted controlled burns to modify the landscape and increase the productivity of certain species is also reasonably well substantiated. This hypothesis was extended by people like Bean and Lawton [7] who suggested that burning also constituted a form of game management:

Burning the woodlands grassbelt, particularly in areas near villages, would have concentrated game in specific locations for ready accessibility in hunting, since browse in burned-over areas would have been richer. Thus we suggest burning may have constituted a form of game management or incipient herding. (Bean and Lawton [7], p. 39)

Throughout Native America, hunters used fire primarily as a means of pursuing large game animals, burning to drive buffalo on the Plains and to capture deer effectively in California [1, pp. 104-105]. On the Plains, the number of buffalo that were taken through the use of fire was enormous (sometimes as many as 1500 at a time), suggesting the lack of any true conservation ethic. On the other hand, it is argued that overexploitation only occurred when Native people began to sell hides and furs in the European-initiated fur trade. According to this idea, overhunting of furbearing animals only began in response to the demands of commercial exploitation and did not exist prior to incipient globalization [11].

None of these ideas were supported with findings from archaeology or paleoethnobotany, and serious empirical evidence from the paleoclimatic sciences in support of the positive effects of Indian burning has not been forthcoming. The management hypothesis was initially developed by anthropologists who relied on historic accounts bolstered by modern-day studies on the effects of burning. There has never been any substantiation of its positive effects on game populations, and empirical evidence supporting the management view is not substantial. 


\section{Legacy of the 1960s II: blitzkrieg}

At the same time that the image of Native Americans as benevolent managers was being promoted by anthropologists and historians, archaeologists contributed to a starkly different vision of the continent's prehistory and the relationships between its first people and game animals. In 1967, Paul S. Martin [12] proposed one of the most influential hypotheses in American archaeology: that the initial peopling of the continent by Clovis big game hunters ca, 12,000 years ago resulted in the extinction of Pleistocene mammals. Martin used simple mathematical equations to suggest that skilled hunters could have populated the entire New World from Asia in a period of about 1000 years during which time Pleistocene mammals were overhunted into extinction. Of course the potential for this type on destructive non-conservative hunting is well attested elsewhere in the world, particularly by the history and archaeology of bird hunting and extinction by the early Polynesian seafarers [13].

Empirical support for this alternative model consisted of (1) growing evidence that the Clovis culture, then-dated ca. 12,000 years ago, represented the initial appearance of human beings in the New World, migrating in from Asia; (2) clear evidence that a multitude of large game species went extinct at the end of the Pleistocene around the same time that human populations arrived; (3) clear association between Clovis projectile points and the remains of Pleistocene game animals; and (4) archaeological evidence for nonconservative hunting practices in the form of massive accumulations of animal skeletons at some sites. This hypothesis, referred to for obvious reasons as blitzkrieg, was accepted by many archaeologists as something approaching near-fact and was included in virtually all archaeology and prehistory textbooks from the 1970s onward. Under this scenario, robust game populations existed in Native North America in spite of indigenous activities rather than because of them.

The degree to which this second hypothesis differed from the first cannot be overstated nor can the fact that aspects of both have been promoted in American academia, and in models of game conservation for nearly half a century, provoking a debate which continues.

\section{Reactionary research of the 1990s and beyond}

Beginning in the $1990 \mathrm{~s}$, researchers sought to examine native-environment relations more carefully and to evaluate some of the alternative ideas that emerged from the 1960s. Consistent with the previous trends, the environmental stewardship hypothesis was largely championed by non-archaeological anthropologists who continued to rely on historic and ethnographic sources e.g. [14,15], while archaeologists have tended to support the overexploitation hypothesis using faunal remains and other empirical evidence from prehistoric sites. Also contributing to the dialog have been American Indian scholars who have, perhaps not surprisingly, tended to support the management perspective e.g. [16].

\section{Resource suppression?}

Foremost among the archaeological studies have been those applying optimal foraging concepts to develop mathematically-based models of optimal diets in particular regions. Using estimates derived both ethnographically and experimentally for potential caloric 
return rates and processing costs, these models feature ranked lists of resources. To subsist optimally in any given resource patch, foragers should target the highest rank resources first, and only pursue lower-ranked foods when the higher-ranked ones are depleted. Two particularly influential papers from the 1990s applied this theoretical approach to faunal remains from archaeological sites to conclude that overhunting by prehistoric peoples caused resource depletion and forced exploitation of lower-ranked foods through time. First, Broughton [17] argued that ca. 500 B.C. in the San Francisco Bay area Native people initially targeted deer, but shifted to the more elusive and difficult to pursue sea otters ca. A.D. 1000 after they depleted the deer populations. Broughton also suggested that sturgeon were overexploited during this time period. Second, Hildebrant and Jones [18] examined remains of seals and sea lions from the coasts of Oregon and California and argued that after prehistoric hunters overexploited sea lion rookeries they were forced to develop elaborate watercraft and maritime weaponry in order to pursue lower-ranked aquatic mammals like sea otters and harbor seals. Both of these papers were highly influential and a flood of similar studies followed e.g. [19-21]. The degree to which this research, particularly Broughton's, was undertaken in direct response to the extreme environmental management views that emerged from the 1960s is fairly clear:

Insofar as my analyses have shown that Native American foragers had profound impacts on the fish, mammal, and bird species of the San Francisco Bay area, they call into question the widely held belief that native peoples maintained a harmonious relationship with the animal populations with whom they shared the land. This belief has led to a 'logical alliance' between Native cultures and conservation organizations. Indeed the government of Columbia has relinquished over 18 million hectares of rain forest to native peoples with the belief that they are best suited to manage it ... Perceived harmony is almost surely a function of limited technologies and low population densities ... There is no compelling reason to think that Native Americans will provide better stewardship of our threatened habitats than any other peoples. [17, pp. 72-73]

Many subsequent faunal analyses, however, have failed to confirm the early claims of overexploitation/intensification models. Larger, more recent studies have in many cases produced less dramatic findings that demonstrate persistence of game populations rather than depletion e.g. [22-25], essentially exposing the overzealousness of the arguments and the smallness of the samples used in much of the initial research. Some studies have demonstrated that the dominant taxa existing prehistorically were different in certain regions and habitats from those of today [26], and others have shown that populations of sea lions were lower in the past at some locations [27], but these studies have by no means demonstrated that such variation was the result of overhunting by human predators. A few studies have demonstrated unequivocal impacts from human foraging on animal populations, however. These include archaeological evidence for the extinction of the highly vulnerable flightless duck (Chendytes lawi) along the coast of California late in the Holocene [28] and a number of studies that demonstrate human impact on shellfish populations e.g. [29].

Broughton's study was also among the first to use hypothesized protohistoric plagues as an explanation for the high numbers of game animals noted at the time of contact by the earliest explorers. Broughton suggested that not long after the arrival of Cortez in Mexico in 1519 that diseases spread across the New World more rapidly than the Spanish 
themselves and that the North American continent witnessed a massive die-off of human populations during the protohistoric period (ca. A.D. 1519-1769). In Broughton's view, depletion of human populations allowed for a massive rebound in numbers of game animals whose populations had been previously suppressed. Others subsequently embraced the notion of a protohistoric rebound in game populations e.g. [30] despite the fact that there is little if any solid bioarchaeological evidence to indicate that such a die-off occurred, at least not in California.

In general, many of the extreme game depletion scenarios advanced from the 1990s onward can be seen as exaggerated and/or lacking in substantive empirical support. Some unequivocal evidence for non-conservative hunting and foraging behaviour has been reported indicating that claims for sophisticated game management are equally unfounded. Studies that have sought to further the environmental management agenda [14-16] have provided good evidence for Native Americans knowledge of the natural environment and its manipulation, but they offer nothing to show that game populations were consciously managed. The optimal foraging-based studies do in most cases clearly demonstrate that hunting was undertaken with self-interest as the leading motivating factor, but it did not seem to result in significant resource depression.

\section{Blitzkrieg refuted}

One final important development from the last two decades of archaeological research has been the general dismissal of the Pleistocene overkill hypothesis. While Martin's model had stronger empirical support when it was first put forward in the 1960s than the environmental management idea, time has not been kind to the blitzkrieg hypothesis [31,32]. While some continue to cling to it [33], 40 years of additional research have added little in the way of additional supporting evidence. The Clovis culture is now firmly dated at 13,300-12, 800 BP [34], but is no longer synonymous with the initial entrance of human beings into the New World since there is now good evidence for human occupation in western North America 700 years earlier [35]. It is also abundantly clear that of the 36 genera of mostly large animals that went extinct at the end of the Pleistocene, only two, mammoths and bison have been recovered in substantial numbers from archaeological sites. It is simply untenable to argue that human beings caused extinction when there is no faunal record of human exploitation for the vast majority of animals that went extinct. Alternative explanations for the Pleistocene extinctions continue to be explored and some are controversial in their own right (e.g. the Younger-Dryas Impact hypothesis) [36], but supporters for Pleistocene overkill are today very few.

\section{Summary and discussion}

The archaeological record represents a potentially critical source of information on past relationships between human hunters and populations of game animals. In North America, the record shows that after more over 13,000 years of exploitation by skilled, knowledgeable hunters, game populations were still exceptionally robust across the continent when the first Europeans arrived. Arguments that the high numbers of game animals reflected population rebound during the protohistoric period when there was a massive die-off of human beings owe more to the theoretical predispositions of anthropologists than they do to the 
empirical facts. Likewise, arguments that prehistoric game populations were suppressed by overexploitation have not withstood serious scrutiny and are not supported by the historic accounts. Equally untenable are arguments that game populations were knowledgeably managed and conserved by prehistoric people since overhunting of one vulnerable, attractive resource (California's flightless duck) caused extinction, and harvest of shellfish led to diminution of mean individual size due to increasingly frequent harvest over time. These patterns demonstrate that exploitation for subsistence was guided primarily by self-interest rather than principles of conservation. Yet, the richness of the North American fauna at the time of contact cannot be overlooked. After more than 13,000 years of non-conservative hunting, game populations seem to have been startlingly large. This implies that the populations of Native hunters were relatively low and also that the former productivity of these ecosystems may be seriously under-estimated by modern conservators.

\section{References}

[1] Krech, S., 1999, The Ecological Indian (New York: W. W. Norton and Company), pp. 1-318.

[2] Higginson, F., 1930 [1630], New England's Plantation. Or a Short and True Description of the Commodities and Discommodities of that Country (New York: The New England Society), no pagination.

[3] Hakluyt, R., 1986, Voyages to the Virginia Colonies (London: Century), p. 75.

[4] Bourne, N., 2010 [1653], Sir Francis Drake Revived (London: Kessinger Publishing), pp. 1-88.

[5] La Perouse, J.F.G., 1968, A Voyage Round the World Performed in the Years 1785, 1786, 1787, and 1788 by the Boussole and Astrolabe (New York: De Capo Press), Vol. 1, pp. 1-179.

[6] Wilkes, C., 1845, Narrative of the United States Exploring Expedition During Years 1838, 1839, 1840, 1841, 1842 (Philadelphia, PA: Lea and Blanchard), p. 113.

[7] Bean, L.J. and Lawton, H., 1976, Some explanations for the rise of cultural complexity in native California with comments on proto-agriculture and agriculture. In: L.J. Bean and T.C. Blackburn (Eds.) Native Californians: A Theoretical Restrospective (Menlo Park, CA: Ballena Press), pp. 19-48.

[8] Lewis, H., 1973, Patterns of Burning in California: Ecology and Ethnohistory (Menlo Park, CA: Ballena Press), pp. 1-xx.

[9] Stewart, O.C., 2002, Forgotten Fires: Native Americans and the Transient Wilderness (Norman, OK: University of Oklahoma Press), pp. 1-364.

[10] Minnich, R.A., 1983, Fire mosaics in southern California and northern Baja California. Science, 219, 1287-1294.

[11] Martin, C., 1978, Keepers of the Game: Indian-animal Relationships and the Fur Trade (Berkeley, CA: University of California Press), pp. 1-226.

[12] Martin, P.S., 1967, Pleistocene overkill. Natural History, 76, 32-38.

[13] Steadman, D.W., 1995, Prehistoric extinctions of Pacific Island birds: biodiversity meets Zooarchaeology. Science, 267, 1123-1131.

[14] Anderson, M.K., 2005, Tending the Wild (Berkeley, CA: University of California Press), pp. 1-526.

[15] Blackburn, T.C. and Anderson, K., 1993, Before the Wilderness: Environmental Management by Native Californians (Menlo Park, CA: Ballena Press), pp. 1-475.

[16] Lightfoot, K.G. and Parrish, O., 2009, California Indians and their Environment (Berkeley, CA: University of California Press), pp. 1-493.

[17] Broughton, J.M., 1999, Resource Depression and Intensification During the Late Holocene, San Francisco Bay: Evidence from the Emeryville Shellmound Vertebrate Fauna (Berkeley, CA: University of California). Anthropological Records 32.

[18] Hildebrandt, W.R. and Jones, T.L., 1992, Evolution of marine mammal hunting: a view from the California and Oregon coasts. Journal of Anthropological Archaeology, 11, 360-401.

[19] Butler, V.L., 2000, Resource depression on the northwest coast of North America. Antiquity, 74, 649-661.

[20] Butler, V.L., 2001, Changing fish use on Mangaia, southern Cook Islands: resource depression and the prey choice model. International Journal of Osteoarchaeology, 11, 88-100.

[21] Kay, C.E. and Simmons, R.T. (Eds.), 2002, Wilderness and Political Ecology: Aboriginal Influences and the Original State of Nature (Salt Lake City, UT: University of Utah Press), pp. 1-342.

[22] Campbell, S.K. and Butler, V.L., 2010, Archaeological evidence for resilience of Pacific Northwest salmon populations and the socioecological system over the last $\sim$ 7, 500 years. years. Ecology and Society, 15, 17. Available online at: http://www.ecologyandsociety.org/vol15/iss1/art17/. 
[23] Jones, T.L., Culleton, B.J., Larson, S., Mellinger, S. and Porcasi, J.F., 2011, Toward a prehistory of the southern sea otter (Enhydra lutris nereis). In: T. Rick and T. Braje (Eds.) Human and Marine Ecosystems: Archaeology and Historical Ecology of Northeastern Pacific Seals, Sea Lions, and Sea Otters (Berkeley, CA: University of California Press), pp. 243-272.

[24] Etnier, M.A.,2002, The effects of human hunting on northern fur seal (Callorhinus ursinus) migration and breeding distributions in the late Holocene'. PhD dissertation, University of Washington. Seattle, WA.

[25] Lyman, L.R., 2003, Pinniped behavior, foraging theory, and the depression of metapopulations and nondepression of a local population on the southern Northwest Coast of North America. Journal of Anthropological Archaeology, 22, 376-388.

[26] Rick, T., Erlandson, J.M., Hildebrandt, W.R., DeLong, R. and Jones, T. L., 2012, Where were the northern elephant seals? Holocene archaeology and biogeography of Mirounga angustirostris The Holocene, 21, $1159-1166$.

[27] Walker, P.L., Kennett, D.J., Jones, T.L. and DeLong, R., 2002, Archaeological investigations at the Point Bennett pinniped rookery on San Miguel Island, California. In: D. Browne, K. Mitchell and H. Chaney (Eds.) Proceedings of the Fifth California Islands Symposium (Santa Barbara, CA: Santa Barbara Museum of Natural History), pp. 628-632.

[28] Jones, T.L., Porcasi, J.F., Erlandson, J.M., Dallas, H.Jr., Wake, T.A. and Schwaderer, R., 2008, The protracted holocene extinction of California's flightless sea duck (Chendytes lawi) and its implications for the Pleistocene overkill hypothesis. Proceedings of the National Academy of Science, 105, 4105-4108.

[29] Erlandson, J.M., Rick, T.C., Braje, T.J., Steinberg, A. and Vellanoweth, R.L., 2008, Human impacts on ancient shellfish: a 10,000 year record from San Miguel Island, California. Journal of Archaeological Science, 35, 2144-2152.

[30] Preston, W., 1996, Serpent in eden: dispersal of foreign diseases into pre-mission California. Journal of California and Great Basin Anthropology, 18, 3-37.

[31] Meltzer, D.J., 2009, First Peoples in a New World (Berkeley, CA: University of California Press), pp. 1-446.

[32] Grayson, D. and Meltzer, D., 2003, Requiem for North American overkill. Journal of Archaeological Science, 30, 585-593.

[33] Fiedel, S. and Haynes, G., 2004, A premature burial: comments on Grayson and Meltzer's "requiem for overkill". Journal of Archaeological Science, 31, 121-131.

[34] Waters, M.R. and Stafford, T.W., 2007, Redefining the age of Clovis: implications for the peopling of the Americas. Science, 315, 122-1126.

[35] Gilbert, M.T.P., Jenkins, D.L., Götherstrom, A., Naveran, N., Sanchez, J.J., Hofreiter, M., Thomsen, P.F., Binladen, J., Higham, T.F.G., Yohe, R.M.II, Parr, R., Cummings, L.R.S. and Willerslev, E., 2008, DNA from pre-Clovis human Coprolites in Oregon, North America. Science, 320, 786-789.

[36] Firestone, R.B., West, A., Kennett, J.P., Becker, L., Bunch, T.E., Revay, Z.S., Schultz, P.H., Belgya, T., Kennett, D.J., Erlandson, J.M., Dickenson, O.J., Goodyear, A.C., Harris, R.S., Howard, G.A., Kloosterman, J.B., Lechler, P., Mayewski, P.A., Montgomery, J., Poreda, R., Darrah, T., Que Hee, S.S., Smith, A.R., Stich, A., Topping, W., Wittke, J.H. and Wolbach, W.S., 2007, Evidence for an extraterrestrial impact 12,900 years ago that contributed to the megafaunal extinctions and younger dryas cooling. Proceedings of the National Academy of Science, 104, 16016-16021. 